This is an Accepted Manuscript of an article published by Taylor \& Francis in

International Journal of Heritage Studies on 9 July 2017 (online), available at http://www.tandfonline.com/doi/full/10.1080/13 $\underline{527258.2017 .1347890}$

You may cite this article as follows:

Colomer, Laia 2017. "Heritage on the move. Crosscultural heritage as a response to globalisation, mobilities and multiple migrations", International Journal of Heritage Studies, http://dx.doi.org/10.1080/13527258.2017.1347890 


\title{
Heritage on the move. Cross-cultural heritage as a response to globalization, mobilities and multiple migrations
}

\author{
Laia Colomer \\ Marie Skłodowska-Curie Fellow \\ Faculty of Arts and Humanities \\ Linnaeus University \\ Linnégatan, 5 \\ 39182 Kalmar (Sweden) \\ Email: 1aia.colomer@1nu.se \\ ORCHID number: 0000-0003-3353-8969
}

Keywords: heritage communities, Faro Convention, deterritorialization, Third Culture Kid, global nomads.

\begin{abstract}
Globalization is creating new perceptions of social and cultural spaces as well as complex and diverse pictures of migration flows. This leads to changes in expressions of culture, identity, and belonging and thus the role of heritage today. I argue that common or dominant notions of heritage cannot accommodate these new cultural identities-in-flux created by and acting in a transplanetary networked and culturally deterritorialized world. To support my arguments, I will introduce "Third Culture Kids" or "global nomads", defined as a particular type of migrant community whose cultural identities are characterised high patterns of global mobility during childhood. My research focus on the uses and meaning of cultural heritage among this onward migrant community, and it reveals that these global nomads both use common forms of heritage as a cultural capital to crisscross cultures, and designate places of mobility, like airports, to recall collective memories as people on the move. These results pose additional questions to the traditional use of heritage, and suggest others visions of heritage today, as people's cultural identities turn to be now more characterized by mobility, cultural flux, and belonging to horizontal networks.
\end{abstract}

\section{Introduction}

Milena $^{1}$ is a 36-year-old woman currently living and working in Vietnam as hotel manager. Her parents, a Christian Hungarian-Serbian and a Muslim Italian-Bosnian, are from the former Yugoslavia. In 1972, they began expat life in China as diplomats because her father was a sinologist during Tito's regime. Milena was born in China and grew up and studied 
there, but she spent a year in Yugoslavia every two years. When the Yugoslav wars started in 1991, her father refused to continue representing his country, and the family remained in China by necessity. When her parents divorced, Milena stayed with her mother, who was then working as an international hotelier. During the following years, she traveled constantly and temporarily lived in dozens of countries all over the world as her mother's career moved. At the age of 15, she moved to Singapore and attended high school at an English medium boarding school, meeting international students for the first time. She became a Canadian citizen during her university studies there. As an adult, she has continued working internationally, travelling and living in many countries, primarily in Asia. She is fluent in English, Chinese, Spanish, Indonesian, and Serbian. When interviewed, she stated: "Yes, we were based in Beijing, but I do not have the feeling of having lived there; I spent a lot of time in a plane".

Milena identifies herself as a global nomad or "Third Culture Kids" (TCKs), a particular type of migrant, defined by high international mobility during childhood and a lack of attachment to any of the particular cultures and national discourses of the countries in which they have grown up. Milena did not choose to move; her parents made that decision based on an increasingly globalized job market. Like any kid, she grew up developing cultural skills and affiliations, but with the major difference of doing so while experiencing both high international mobility and the serial processes of multicultural integration. As an adult, she does not feel a sense of belonging to any one culture or place/country. We may say instead that she is the heir to an increasingly globalized world. In her case, globalization not only describes a social, economic and political momentum but also the formative condition of her childhood. As we will see, Milena, like most adult TCKs, has an approach to heritage and 
collective memories directly connected to onward mobility, the deterritorialization of culture, and to the formation of community identities in a network society.

Building on the above narrative and following current trends in the sociology and anthropology of globalization and mobilities, this paper will advocate that heritage studies also shifts its focus from culturally fixed essentialist categories to the flows and fluxes of people's cultures, identities, and attachments. For that I suggest to move our focal point to people, as the subject of action in giving meaning and attributing value ${ }^{2}$ to heritage. Heritage is thus viewed "as the interaction between people and the world, and between people themselves" (Holtorf and Fairclough 2013, 198; see also Fojut 2009; Schofield 2015). I will argue that because globalization embeds increasing forms of deterritorialization (see Papastergiadis 2000; Scholte 2005; Tomlinson 2003), and because mobility has become both a fundamental social issue and an inclusive category (see Adey et al. 2014; Cresswell 2006, 2010; Glick Schiller and Salazar 2013; Urry 2007), it is worth developing visions of heritage that better capture how these particulars are affecting, not cultures as defined containers, but people's cultural identity, and consequently how people both use current forms of heritage and give (new) meanings to heritage. In this context, I frame my work on the notion of heritage as developed by the 2005 Faro Convention of the Council of Europe (see also Council of Europe 2009) which adopted a people-centered perspective and established that heritage must have a purpose to everyday public life, for example in terms of values, identity, social integration and economic sustainability (see also Fojut 2009; Holtorf and Fairclough 2013). The Faro's notion of "heritage communities" is of relevance here as a category of analysis to visualize a cluster of people connected despite distance and by the fact of not sharing a common territory. 
To support my arguments, I will introduce Third Culture Kids (or "global nomads", as they also like to be referred). Their particular features makes them suitable to illustrate the complexity of this new cultural and sociological phenomena of "deterritorialization of culture", providing a rich source for reflection on the effects of globalization for current and future conceptions of heritage. As members of a community of global onward migrants, global nomads develop both other visions on the use of heritage while crisscrossing cultures, and attachment to places according to their shared collective memories. I refer to the resulting heritage as "cross-cultural heritage", a concept derived from the particular meanings given by people to their surroundings as they move and live between places and cultures. Crosscultural heritage thus tries address a key question in heritage studies today: what would be the heritage of citizens whose collective identity is not based on a sense of ethnic, cultural or national belonging?

\section{Heritage and globalization}

Scholte (2005) notes that globalization today is not interchangeable with terms such as "internationalization" (i.e., transactions and interdependence between countries through crossborder activity), "liberalization" (i.e., removing officially imposed restrictions on the movement of resources between countries), "universalization" (i.e., a process of dispersing various objects and experiences to people all around the world), or "Westernization" (i.e., regarding a particular type of universalization). By contrast, the sociology of globalization argues instead that globalization is currently defined by transplanetary and supraterritorial connectivities, which underpin a completely different paradigm of social space beyond the territorialism of modernity (e.g., Appadurai 1996; Beck 2000, 2005a; Castells 2010a, 2010b; see also Held and McGrew 2003). Transplanetary and supraterritorial connectivities refer to social links between people located at points anywhere on earth. These connections provide a 
distinct arena of social life beyond the exchange between countries with inter- or transnational relations (Scholte 2005, 59-84; but see also Appaduarai 1996's global ethnoscapes, Beck 2000's cosmopolitan paradigm of second modernity, and Castells 2010a's network society). These new relations are qualitatively different (e.g., denser, intense, instant and simultaneous) and cannot be adequately mapped on territorial grids (Scholte 2005). They go beyond national identities, as people's connectivity is no longer territorially monopolized in the same way. More people live in the social spaces of the local and the global arenas, and not exclusively in those of the nation. When exploring the impact of globalization and migration in established notions of belonging, Papastergiadis uses the term deterritorialization of culture to refer to this phenomenon and defines it as

the ways in which people now feel they belong to various communities despite the fact they do not share a common territory with all the other members. It also refers to the way that a national or even a regional culture can no longer be conceived of as reflecting a coherent and distinct identity. This gives attention to the ways communities are connected despite distance, and redefined through exchange, has challenged earlier assumptions that cultures could be mapped into autonomous and bounded spaces. The authenticity of a cultural formation is no longer singularly linked to its physical proximity to a given cultural centre (Papastergiadis 2000, 208)

In the field of global studies, heritage literature tends to focus on one of two issues. The first involves the effects of globalization on cultures, which are understood as connected to sovereign nation-states, particularly in regards to the internationalization of Western heritage conservation and management practices (e.g., Harrison 2013; Labadi and Long 2010; Meskell 2015). The second includes the politics and ethics of intercultural postcolonial encounters that globalization is intensifying (e.g., Biehl et al. 2015; Meskell 2009), and encourages reflexive 
and critical examinations of westernized heritage practices among indigenous or minority groups. In both cases, globalization is largely understood in terms of Westernalization (i.e., the universalization of the social structures of modernity; Scholte, 2005, 58) or internationalization (i.e., a growth of transactions and interdependence between countries or communities; Scholte 2005, 54-55), and it is examined on the same ontological and methodological grounds as modern rationality (Scholte 2005, 257-259 and 264-266; see also Beck, 2005b), a tendency to characterize and mediate cultures as "substance" (Appaduari, 1996, 12), as unities of cultural uniqueness and authenticity rather than as the result of ongoing practices of community hybridization (e.g., Papastergiadis 2000). Without dismissing the existing of Westernalization processes in heritage management and its political and ethical consequences, this article aims to turn our attention to the fact that globalization has also led to fundamental changes in people's geopolitical and sociological landscapes, touching people's capacity in defining their cultural identity and community belonging, and consequently the meaning of heritage for them. In relation to this, Tim Winter (2014) offers a timely reminder that heritage studies has not yet debated this theorization at the global level. Consequently, it needs to seriously address both the heterogeneous nature of heritage and the conceptualization of multiple heritages.

\section{Heritage and migration}

Milena's short account above exemplifies the ways in which globalization processes are changing the characteristics of people's mobility. The United Nations (2013) calculated that in 2013, the number of international migrants worldwide reached 232 million, a substantial increase from 175 million in 2000 and 154 million in 1990. This has affected both developed and developing countries, and contrary to perceptions in developed countries, South-to-South migration slightly exceeds South-to-North migration (see also Castles, De Haas and Miller 
2013). The classic sociological profile of the migrant as an impoverished non-White man has also changed. People of all statuses and classes, including a growing numbers of solo women and unaccompanied children, are on the move (e.g., Anthias and Lazardis 2000). More relevant to the present discussion is the fact that today's migrations may include several moves in a life's journey, as there is not necessarily any fixed final destination (Ossman 2013). This mobility encompasses multiple paths, multiple directions and multiple relocations. Along these multiple journeys, people perceive, understand and negotiate their different encounters not only in relation to their culture of origin but also according to the experiences gained during their relocations. These negotiations are visualized in numerous ways, including social and cultural identity construction and in the sense of place and belonging (e.g., Ossman 2013). In addition to the traditional push and pull of market forces on mobility, other motivations are playing important roles, such as those based on gender wellbeing, living conditions, social freedom, and career trajectory, not necessarily related to better salaries (Fassman et al. 2009). Further, mobility has become easier to imagine and sustain as a result of low cost transportation and new communication technologies, which enable migrants to remain connected with places of origin and to often travel back and forth (Fassman et al. 2009). Finally, current mobility patterns also show that people's migration is not an anomaly of sedentarism, or something that happens occasionally to reach another place, but a constituent action full of significance and meaning per se, affecting equally those who move and those who do not. Accordingly, when analyzing immigration in the UK, Steven Vertovec (2007) rightly notes that it is not enough to see diversity only in terms of ethnicity. Other relevant variables need to be added, such as differential immigration status, gender and age profiles, migration channels, spatial distribution and degree of mixture with other residents, locality and access to employment, and capacity of transnational 
engagements. These observations point toward a need to go beyond studies on socioeconomic migration, segregation and other issues based on ethnic or immigrant classification alone.

The key question is thus whether it is possible, in the scenario of global migration flows, "to draw on memory and heritage to form new identity stories that include rather than exclude cultural diversity and 'mixed' cultures" (Macdonald 2013, 162). In a chapter dedicated to transcultural heritage, Sharon Macdonald (2013) explores how national heritage managers and museums have struggled to address the current changing identity constellations of Europe, by considering the potential of existing monuments and collections to tell new memory stories. Perla Innocenti (2015) answers this question by addressing the concept of "migrating heritage", described as resulting from the power of cooperation in a technologically based networked society, assuming that "cultural networks at local, national and transnational levels can contribute to the development of new models and institutional practices of heritage within cultural institutions" (Innocenti 2015, 6). However, the struggle in both cases is how these debates over citizens' identity transformation represented in museums could be sustained in national institutions without making them discrete cultures again. After discussing how the Museum of London has dealt with issues of diversity and migration in their exhibition rooms following alike debates in UK academia and public institutions over the last two decades, Cathy Ross (2015) moves a step forward and, while observing a postnational metropolis such as London today and its globalized residents, notices:

...it may be useful to move away from the idea of migration as being settled communities. Today, migration feels more like a state of constant movement with individuals passing through London, staying perhaps for few years and then moving on. London today may be better imagined as a perpetual motion machine rather than a place to pitch your tent and stay (...) but does it make them any less representative of 
the experience of being a Londoner in the twenty-first century? (Ross 2015, 76 and 77)

The question that remains unanswered in heritage studies is therefore how to incorporate mobility and hibridity as a normalized practice rather than one in opposition to territorially based and discrete cultural entities.

\section{The community of TCKs}

When using the terms "global nomads" or "Third Culture Kids" (TCKs), I am referring to children who spend a significant number of their formative years outside their parents' native culture(s), and who live in several countries other than the one stated on their passport during that time. While abroad, they acquire meaningful relations with other cultures (after Pollock and van Reken 2009). The term TCK was originally coined in the 1960s by R.H. Useem to sociologically define US children who grew up while following their parents abroad. Traditionally, TCKs represent the children of expatriate groups, such as members of the diplomatic service, corporate employees, military personnel, or missionaries. Today, they include increasing numbers of children of people moving abroad due to career choices in a globalized labor market (e.g., researchers and academics, skilled workers and individual entrepreneurs, NGO employees, international journalists, international school educators, professional sports people, etc.), but also independent families that simply look to improve their quality of life. The term is popularly applied to children of "expat" parents rather than those of "migrants" parents (see Remarque Koutonin 2015). However, some scholars have recently noticed a middling process of global/continental multiple mobile migration, which they define as "onward migration" (Lindley and van Hear 2007) or "serial migration" (Ossman 2013), and which mobility profile matches with TCK parents or TCK themselves. In 
this new context, it is clear that the term "Third Culture Kids" will need a better definition in sociological terms if we aim to continue using it (see also Tanu 2015$)^{3}$. Nevertheless, since Pollock and van Reken's (2009) work, an increasing quantity of material has been published by adult TCKs, including articles, books, or simple short entries in e-magazines, personal blogs, and Facebook groups. This growing visibility has encouraged the first works in sociology and social anthropology (e.g., Benjamin and Derwin 2015; Désilets 2015; Tanu 2015) as well as extensive studies in social psychology and international education (e.g., Bagnall 2015; Fail, Thompson and Walker 2004; Moore and Barker 2012; Trąbka 2014). All these works coincide in defining TCKness by the lack of cultural ownership, a sense of liminality between cultures, and sense of community distinguished from other migrant/expatriate and diaspora groups, based on their onward mobility during their formative years.

(Figure 1 - Image DSF7020_Anna)

While traditional migrants leave one country to live in another, causing them to experience $l a$ double absence (Sayand 1999), developing cultural attachments both in their culture of origin and their culture of adoption, global nomads grow up in several different cultures to the point of blurring the notions of "origin" and "adoption". The question TCKs most dread is therefore "Where do you come from?", because it is unclear to them what the question is referring to: their current home, upbringing, passport, family background, ethnic affiliation, or cultural identification. Adult TCKs identify themselves as a community distinct from diaspora, migrant and 'expat compound' groups not because of their cultural origins or their adopted culture but because of their condition as serial migrants during their formative years (Désilets 2015). Whereas migration studies uses terms such as hybridity, biculturalism or creolization 
to stress how identity is negotiated between the culture of origin and the culture of arrival, global nomads might not feel that they have a single place of origin or arrival with which to negotiate; instead, they have many of both.

Social psychology and neuroscience maintain that high mobility during people's formative years affects the behavioral of those parts of their brains that develop culturally and socially adult personalities, to the point of developing other ways to perceive, imagine and behave in the world (Solms and Turnbull 2002; Trąbka 2014; Wasserman and Zambo 2013). In the case of TCKs and despite the variance in personal mobility trajectories, their experiences coalesce around the feeling of living between cultures, or being stuck permanently in the position of cultural outsider, which leads to a negative sense of cultural dispossession as well as a positive, strong sense of "multicultural identity" or "multiple cultural identities" (Moore and Barker 2012, 559). This sense of liminality expressed in terms of multiculturalism is what allows adult TCKs to go beyond both territorialism notions of place, belonging and origin.

\section{A first approach to global nomads' cultural identity and heritage}

To analyze the links between mobility, cultural identity and heritage among adult TCKs, my research combined two types qualitative research methods: an electronic questionnaire and indepth online interviews with a selected number of participants. The electronic questionnaire represents the most convenient way of gathering information from a population that by definition is living anywhere in the world. The e-survey was posted in several social media online forums and web pages on and for adult TCKs, emailed to particular already known adult TCKs or researchers working with TCKs, and to several international organizations with direct contact with TCKs (e.g., alumni of international schools). It has always been asked to 
spread the existence of this e-survey to create a snowball effect among adult TCKs. Between June and September 2016, the questionnaire gathered 146 responders aged 18+ who had spent at least one year of their childhood in more than two countries. The e-survey included openended questions and range questions, and was designed based on a critical analysis of current literature produced by and on TCKs. It also draws on an earlier pilot e-survey conducted in 2015 (see Colomer and Holtorf forthcoming). A simple statistical analysis of the data has provided insights into notions and experiences tied to cultural identity, as well as to global nomads' conceptions of tangible and intangible heritage. The 10 in-depth online interviews, conducted in the fall 2016 and winter 2017, were structured based on a number of key questions that helped define the areas to be explored, but still allowed the interviewee to diverge in order to pursue an idea or go into greater detail. Interviews thus served to clarify previous answers and to gain a deeper understanding of the senses and uses of heritage among the TCKs, along with their collective memories of mobility and takes on cosmopolitanism, multiculturalism and homemaking processes. Here I will summarize these results and give two short examples of both how heritage is meaningfully used, and how other materialities better account their collective memory.

The average profile of respondents is that of a female between 36 and 65 years old with one passport (either from the USA or the UK), who is fluent in three languages (usually English, Spanish and French) and has lived in at least three different countries in her childhood. The time spent abroad usually occurred as a result of business and career choices or the economic necessities of the respondent's parents. The average participant combined international schools (following an international curriculum) and local schools (following local national curriculum). An initial exploration of the participant's sense of belonging and identity showed a strong connection to a nomadic life across places and cultures. "Global mobility" (74\%) and 
"multiculturalism" (69\%) were considered more important for identity construction than religion, sexual orientation, gender, birthplace, passport, school, socioeconomic condition, and current place of residency. Including further questions about participants sense of belonging and identity, this initial exploration confirmed that participants' profile matches with the described above for TCKs. After, the e-survey explored first, the use of common forms of heritage; then asked about TCK's collective memories; and finally, explored their perceptions on UNESCO WH Sites as places significant for people with a multicultural profile. In this article T will describe and discus the results of the first two blocks.

The first part of the e-survey explored whether participants recognize local and national heritages as significant to their global nomad and multicultural identity. Their answers reveal that current forms of cultural heritage are of value to global nomads but this affirmation needs to be clarify. First, they accepted (61.4\%) that local/national cultural heritages help them establish their cultural identity as global nomads. But $46.6 \%$ responders agree that only national heritages are relevant for that purpose. Particularly national, regional, city and cosmopolitan city heritages individually are not highly pondered (less than 20\%) as suited here, even there is a tendency to recognize the relevance of cosmopolitan city $(12 \%)$ in front national heritages $(8 \%)$. Instead, when the optional answer was "...the mix of different cultural heritage" participants clearly recognized its value (more thàn $40 \%$ ). During interviews participants were asked to explain these particulars, and then it was revealed that even national heritages are significant, they are not the most relevant in representing their cultural identity. Local heritages play a similar role. Because global nomads have lived in several nation states, attended regular schools, and understand the relevance of borders and passports in a globalized world (Désilets 2015), heritages operate as a sort of contributory (adaptive) condition for them. Encounters with multiple national and local heritages become 
transformed into Bourdieu's embodied cultural capital. Separately, they act as tools for integrating into each particular culture; together, they become what may be called multiculturalism, which does not have a defined cultural form but helps global nomads to transition between cultures. Moore and Barker describe it accurately: "they have the ability to shift between different cultural identities or blend identities without necessarily feeling a sense of belonging to any of them" $(2012,559)$. When asked whether their multicultural life is represented in any type of local/national cultural heritage, almost $55 \%$ of responders considered that it does not (as opposed to $17.3 \%$ who did). One of the interviewees was very clear about this: "I visit national museums; and it is very interesting to know about their culture; but it is not about $m e^{" ~(I b o, ~ o r i g i n a l ~ e m p h a s i s) . ~ I n s t e a d ~ p a r t i c i p a n t s ~ b e l i e v e ~ t h a t ~}$ "...the mix of different cultural heritages" $(67 \%)$, "...the cultural heritage around the world" (47\%), and "...the natural landscape" (47\%) are the best scenarios in which to build their identity. The first two statements clearly denote the global and multicultural profile of these responders, whereas natural landscapes are selected because (based on comments extracted from several interviews) they are considered to be the places in which cultural belongings and identity negotiations do not occur, spaces devoid of human cultural interaction.

When asked about the type of unique collective memories that people experiencing crosscultural lives might share, the majority of responders considered multiculturalism (82\%), multiple moves $(80 \%)$, mobility $(78 \%)$, and globalism $(78 \%)$ to be the most relevant, followed by international schooling (71\%), restlessness $(65 \%)$, rootlessness $(55 \%)$, and cosmopolitanism (54\%). Furthermore, they believed that the cultural heritage of global nomads must address or represent either "...the experience of being nomad" (78\%), “...multiculturalism" (78\%) or "...globalism" (69\%). Participants were after asked to openly name places, objects or performances that might represent global nomads' collective memory. 
The answers are varied, but certain topics or items reoccur: cooking and food diversity, music and performance arts, storytelling (particularly those of other global nomads), natural places, international schools (as multicultural/TCKness meeting places). Furthermore, there are a lot of references to places or objects related to mobility, particularly airports, passports, suitcases, time zone charts, transportation tickets, and all kind places of transportation (e.g., buses, trains and roads, depending on each personal experience).

Airports are certainly a common reference in most publications about and by adult TCKs (e.g., Iyer 2000, chapter 2). To determine whether this phenomenon is part of their collective memories, the e-survey included two further questions regarding these particular issues with a selected number of categories. They cover a variety of options denoting mobility and stillness (for comparative purpose) as well as places and objects that are old or contemporary, iconic or novel. Highest rated were "airports" (76\%) and "suitcases" (69\%) followed by so-called "sacred objects" (58\%), "Internet/networking" (57\%), "cosmopolitan cities" (55\%), and "railway and bus stations" (53\%). When asked how these same categories are relevant to their personal emotional attachments, responders equally, if not increasingly, sympathized with airports $\left(63 \%^{5}\right)$, "sacred objects" (60\%) and cosmopolitan cities (59\%). The positive reaction toward airports challenges contemporary perceptions of airports as 'non-places' (Augé 2006), as spaces of circulation, consumption, and communication which cannot be defined as relational, or historical, or concerned by identity' (Augé 2006, 77-78). According to Augé, airports are elements in the middle of a meaningful landscape that do not belong there but act as mere transit knots between places and people. They are anonymous, disorienting and offputting places that people try to avoid. However, in the eyes of global nomads, as expressed in my e-survey and the subsequent interviews, airports are among the most significant places in their lives, a place where TCKs feel comfortable (48\%). Of the participants, $45 \%$ did not 
agree with the idea that airports are places full of solitude and isolation, as lacking in personality $(53 \%)$, or as places to avoid unless for travelling (38\%). Airports are meaningful spaces for global nomads, as they are "the only fixed place emotionally related to our past, present, and future" (Iyer 2000, 67).

(Figure 2- image DSF9540_Anna)

The second element referenced by participants is "sacred objects". I suggest that the examination of these objects need to go beyond traditional modes of interpreting material culture, for instance, as mere souvenirs or cultural markers of the homeland. In the anthropology and heritage of migration, movable artifacts become "empowering mediators in the construction of a transnational sense of selfhood" (Svašek 2012, 14) both in relation to the past ("it is part of my history"), and in relation to the present ("this represents who I have been and I am"). Sacred objects have additionally the effect of empowering TCKs in the future, as they make further serial relocations emotionally easier ("as far I carry this object I can move to another place"), embedding thus a flux condition. Furthermore, sacred objects have also the important role of home-making in mobile life: they embody the sense of home that the owner has experienced, created, recreated, and embedded in his or her different dwellings. Since among adult TCKs home is "a feeling rather than a place" (Désilets 2015, $145)$, it is thus interesting to further examine the interchangeable phenomenon of sacred objects both embedding the intangible sense of home and becoming the only tangible form of home.

\section{Cross-cultural heritage in the context of globalization}


Participants to my research approach to common forms to heritage differently due to their cross-cultural and mobile life experience. In addition, they recall other places and objects to signify their collective memories. Here I will both discuss these particulars in the context of the sociology of globalization and the mobilities turn, and open thus a gaze on how they can be conceptualized in heritage studies. I refer it as cross-cultural heritage, and aims to provide a different view from which to address alternative forms of valuing the collective memories of citizens embedded with multiculturalism and mobility.

One of the effects of globalization and current forms of mobility is that "social action must be reimagined as possibly be able to take place 'at-a-distance', and that ideas about home and not-home, local and global, must be substantially rethought" (Skrbi $\square$ and Woodward 2013, 58). In the framework of the network society, Manuel Castells calls this phenomenon the "space of flows" (or the technological and structural possibility of organizing the simultaneity of social practices without geographical contiguity; Castells 2010a). He further explores how these network flows prelude the creation of different kinds of collective identities beside the dominant "legitimizing identity" (Castells 2010b). Global nomads do not represent a resistance movement opposing the new global order. They are better described as a proactive, identity-gathering group who "build interests, values, and projects around experiences and refuse to dissolve by establishing a specific connection between nature, history, geography, and culture" (Castells 2010b, 425). Similarly, Appadurai refers to the "community of sentiment" as a group that "begins to imagine and feel things together" while creating postnational sodalities (Appadurai 1990, 8). These identities, such as global nomads, crisscross the new global context and call for other forms of coexistence that might be defined as a cosmopolitan ethos (Skrbi $\square$ and Woodward 2013, 10-16), or embedded multiculturalism. I describe these practices of identity process as horizontal because they are determined not by 
ethnic or cultural affiliations transformed into national or minority group projects, but by a community of peers whose commonality, is defined by the embodied experience of high international mobility during childhood, and its consequence in the construction of subjective identity - a particular experience that creates distinctive shared collective memories. Accepting the existence of these horizontal and deterritorialized ways of collectively being, acting and remembering, means that heritage studies needs to develop methodological tools that take into account their collective memories.

The notion of "heritage community", first suggested at the 2005 Faro Convention of the Council of Europe (Council of Europe 2005), may help us in that purpose. The Faro Convention affirms that heritage should genuinely reflect citizens' responsibilities for the attribution of heritage values, and for that develops the notion of "heritage communities" which consist of "people who value specific aspects of cultural heritage which they wish, within the framework of public action, to sustain and transmit to future generations" (Council of Europe 2005, Article 2b). These people may be unrelated in terms of territory, cultural background, place of residence or social context but nevertheless form a distributed community (see also Fojut 2009; Holtorf and Fairclough 2013). In the case of global nomads, the notion of a 'heritage community' recognizes their uses and perceptions of heritage in the absence of defined geographical origins and cultural backgrounds. It also operationalizes how to value landmarks of collective memory (like airports and other places of mobility) as significant heritage places. As analytical category, it is thus a first step in designing other forms of engagement and giving significance to other forms of heritage perceptions (Colomer and Holtorf forthcoming; see also Schofield 2015). 
If the global nomads represent a heritage community, the heritage that emerges is what I call "cross-cultural heritage", and it derives from particular meanings given by people to their surroundings as they move in between cultures ${ }^{6}$. When defining cross-cultural heritage, it would first need to consider how participants in my research have a chameleonic way of using common forms of cultural heritage. Heritage is understood as a tool for culturally navigation and social integration while crossing borders; it is not considered a source or representation of cultural identity. National and local heritages are embodied as cultural capital, but they do not enter into the subjective identity level of the individual. As Isar, Viejo-Rose and Anheier notice $(2011,9)$, the old lieirx de mémoire seem to have lost much of their power to forge and sustain a single vision of the past, but they remain useful in negotiating their respective cultural and identity differences (i.e., Ashworth, Graham and Tunbridge 2007). Global nomads add a new dimension to this occurrence, as they use these lietx to navigate along cross-cultural life experiences and to add value to their multicultural identity without fully identifying with them (in terms of subjective cultural identity) because these lieux do not represent "mobility". It is certainly a different way of using heritage in a transmigration context. Regarding collective memories, it is interesting to notice a division. Participants in my survey distinguished among those things and performances that denote multiculturalism, and those that denote mobility. The former is usually represented through forms of common intangible heritage, such cuisine, and music and art performances. These are cultural expressions that traditionally have celebrated diversity and permit the reconfiguration of differences, and thus accept re-creations under the form of creolization and hybridization practices. Mobility instead, does not have any representation in common forms of cultural heritage and therefore TCKs turn their attention to other places and objects on the move, like airports. 
The ability of 'mobilities' (Adey et al. 2014; Cresswell 2006, 2010; Glick Schiller and Salazar, 2013; Urry 2000, 2007) to focus on the phenomenology of human interactions with spaces and objects in a networked and fluctuating society helps to shape cross-cultural heritage in relation to adult TCKs' collective memories (as in Halbwachs). Mobilities transform location into a set of relations, and therefore, society and culture also move from being fixed in place to being understood both as an amalgamation of mobile spaces and as movement from one place to another. Here meaning is included in movement (Cresswell 2006), which in turn helps to signify, for example, airports as meaningful places, as a "placeballet" (Cresswell 2006, 257) of actions, experiences, affections, and memories. For adult TCKs, airports are the places in which their global mobility occurs, and singularly symbolize the transitional life and their in-flux worlds, the movement and the journey. It is obvious that airports are not built to engage with the past neither to become elements of the interest for archaeologists or heritage managers. They are basically architectures for the transportation of objects and people. Their relevance as heritage places does not derive from the space itself (cf. Harrison and Schofield 2010, 250-258), but the emotions that people are able to attach to them, the meanings and interpretations that people invest in them. The potential value of these places of mobility as actual heritage places thus arises from the affection invested in them by this particular community of users who see them as part of their collective memories assuming here that affect is a form through, and with which, the world is considered, acted, perceived, and consequently remembered. Airports (or any other places where mobility is performed) act as a metaphor for a deterritorialized global, displaced and dislocated life. They represent the material culture of mobility.

\section{Conclusions}


Globalization is neither the end of the nation nor of cultural diversity, but of their reconfiguration. Although traditional notions of belonging and identity recalled in heritage narratives may be of value to moored communities and modern nations, they are becoming increasingly restrictive to citizens on the move and in a networked society. Based on this new context, a central issue for social sciences is to examine the way in which nation-states and cultures become denationalized and deterritorialized (and no longer internationalized) owing to the cultural capital of an emerging networked and mobile society. The key question is how do people with plural destinations, multiscale journeys and diverse embodied cultural encounters define and represent their multicultural realities. It becomes particularly pressing in the case of adult TCKs, whose social and cultural capital is defined by the lack of singular geographical anchors and cultural attachments, or at least to those related to the territorialism of the nation-state.

Today, global nomads represent an extreme case of mobilities and multicultural identities, but in the future, they will be part of a mainstream pattern rather than an exception (Friedman 2007). Globalization today has not only provided the means to move (e.g., low-fare flights, EU Schengen, relocation of production and workforce) but also fostered a mentality that allows all kinds of people to imagine transnational and transcontinental migration as a real option (Salazar 2012). Once migrants have encountered and overcome one international move, they acquire the personal and cultural (and sometimes legal) capital to migrate again. As many parents enter into the dynamics of multiple migrations, more children are going to grow up in-between places and in-between cultures, and with the sense that multiple migration is a "natural" occurrence. In this context, TCKs' experiences might help us to foresee what belonging and identity could mean in a globalized world, and consequently, the meanings and uses of heritage for cross-cultural people in the future. It will be important to 
increasingly understand that cultural heritage in this arena is not used to recall roots, but to come to terms with routes.

In this scenario, heritage studies may need to move its analytical eyes from past elements that have been fixed geographically and culturally to places and materialities representing mobile lives. The latter not only represent the departure and arrival of people, both physically and metaphorically (as is common in the heritage of migration and post-colonial studies), but their continuous flow and mobility and how this experience develops in other visions. To understand such groups there is a need to move away from essentialist forms of cultures and heritages to a more open process of creating the meanings of heritage in dialogue with (networked) community of heritage users. My research demonstrates that adult TCKs or global nomads not only share a cross-cultural lifestyle and multicultural identity but also distinctive collective memories. These memories forge and sustain a vision of a shared past experience, which helps them to identify themselves and cope with the uncertainties surrounding 'us' and 'them'. Based on the results, it is clear that the use of common forms of heritage in an operational way among multicultural onward migrants is another way of investing meaning and value to heritage. Next to this, we may need also to acknowledge the existence of other objects and places as potential heritages for people living on the move. While a lot of research remains to be done, cross-cultural heritage endorses the potentiality of engendering innovative approaches in heritage studies, focusing on the relations between mobility, identity, belonging, collective memories and their physical expressions in (in)material culture. 


\section{Notes}

1 Milena is participant number \#071. Milena is a fictitious name.

2 Here, I use the notion of value as defined by English Heritage (2008), which lists four types of values relevant to conservation: evidential value, historical value, aesthetic value, and communal value. The last one is of special interest here, as its assessment resides in the opinions and feelings of members of the public: "Communal value derives from the meaning of a place for the people who relate to it, for whom it figures in their collective experience or memory" (2008: 31, paragraph 54). Places and objects that embody these values might be of commemorative, symbolic, spiritual or social value and thus important aspects of collective identity because of the emotional links attached to them. The document therefore defines the notion of social value as "places that people perceive as a source of identity, distinctiveness, social interaction and coherence. Some may be comparatively modest, acquiring communal significance through the passage of time as a result of a collective memory of stories linked to them. They tend to gain value through the resonance of past events in the present, providing reference points for a community's identity or sense of itself. They may have fulfilled a community function that has generated a deeper attachment, or shaped some aspect of community behavior or attitudes (...) They may relate to an activity that is associated with the place rather than with its physical fabric. The social value of a place may indeed have no direct relationship to any formal historical or aesthetic values that may have been ascribed to it" (EH 2008, 32, paragraph 56 and 57).

3 The purpose of my research is not to undertake the task of defining TCK's sociological profile. Neither I took for grant that they are a (sub)culture. In fact, my survey explored how adults with a childhood touched by global mobility during childhood relate to cultural heritage. Accordingly, I limit the subject population of my research to those who (regardless of their passport, the reason for their parents' mobility or knowledge of what means TCK) lived in at least 2 countries beside the one on their passport country for a significant time (defined as 1 year). For practical reasons and with the aim 
avoiding new terms without clear sociological profiles, I will alternatively use the term 'global nomads" when referring to TCKs. Furthermore, I use the category of "culture" as defined and used by my participants, without any aim to counter or support their notions, even if they are extensively using this category in a discrete and substantive mode, as in "culturespeak" (Hannerz 1999; Wikan 1999; see also Grillo 2003 for discussion).

4 In the world of TCKs, "sacred objects" are objects that children take with them (or parents encourage them to take) when they move to a new home. These objects help them to remember their past and feel at home in the new place (Pollock and van Reken 2009).

5 This reduction of $13 \%$ was explored during the interviews. The question in the survey used the phrase "positive emotions", and thus not all responders agreed with it despite their connections with airports. Participants developed strong emotions regarding airports, but those emotions were not necessarily positive. Because airports are the anteroom for uncertain new relocations, the doorway to loved friends and family, and the gateway to repeated farewells, global kids viewed them with contradictory emotions, ranging from sadness, fear, anger, joy, stress, surprise, happiness, caution, confusion, etc.

6 In the present study, the term 'cross-cultural heritage' denotes the heritage that traverses single cultures, is formed by life-experiences characterised by frequent moves and influenced by a variety of cultures. Although all manifestations of cross-cultural heritage vary and there is no single crosscultural culture, there are some charactersistics that tend to distinguish cross-cultural heritage from other (single-)cultural heritage.

\section{Acknowledgements}

This paper largely benefited from the advice and critical comments of Anders Högberg, and from early talks on heritage and TCKs with Cornelius Holtorf and Ian Lilley. I acknowledge also Jaime Almansa Sánchez and Sharon Macdonald for their comments on the e-survey 
design. Thanks also to the anonymous referees for their comments that contributed greatly to improvements to this manuscript. Finally, I would like to specially thank all participants of the e-survey and those who kindly accepted to be interviewed.

This work is funded by a Marie Skłodowska-Curie Individual Fellowship, as part of the European Union's Horizon 2020 Research and Innovation Programme (grant agreement No. $658760)$.

\title{
Declaration of conflicting interests
}

The Author declares that there is no conflict of interest.

\section{Notes on Contributor}

Laia Colomer is an archaeologist with extensive professional and academic experience in archaeological heritage management and public archaeology. The question currently driving her research focuses on how particular heritage communities use and develop cultural heritage to reinforce or redefine their identity in an increasingly globalized world. She was educated in Barcelona ( $\mathrm{PhD}$ in Prehistory Archaeology, $\mathrm{UAB}$ ) and in London (MA in Public Archaeology, UCL). She has combined an academic career in The Netherlands, the UK, Spain and Sweden, with a professional career in cultural heritage management in Spain and Italy, including in both paths several European Commission projects.

\author{
References \\ Peter Adey, David Bissell, Kevin Hannam, Peter Merriman, and Mimi Sheller. 2014. \\ "Introduction". In The Routledge Handbook of Mobilities, edited by Adey, P. et al., 1-20. \\ London: Rotledge.
}


Anthias, Floya and Gabriella Lazardis, eds. 2000. Gender and Migration. Women in the Move. New York: Berg.

Appadurai, Arjun. 1996. Modernity at Large. Minneapolis: University of Minnesota Press.

Ashworth, Greg, Brian Graham and John Tunbridge. 2007. Pluralising Pasts. Heritage, Identity and Place in Multicultural Societies. London: Pluto Press.

Augé, Marc. 2006. Non-places. Introduction to an Anthropology of Supermodernity. (1 ${ }^{\text {st }}$ published 1995). London: Verso.

Bagnall, Nigel. 2015. Global Identity in Multicultural and International Educational Contexts: Student Identity Formation in International Schools. New York: Routledge.

Beck, Ulrich. 2000. "The cosmopolitan perspective: sociology of the second age of modernity", British Journal of Sociology, 51(1): 79-105.

Beck, Ulrich. 2005a. Power in the Global Age. Cambridge: Polity Press.

Beck, Ulrich. 2005b. "The cosmopolitan state. Redefining power in the global age", International Journal of Cultural Sociology, 181: 143-159.

Beck, Ulrich and Natan Sznaider. 2006. "Unpacking cosmopolitanism for the social sciences: a research agenda". British Journal of Sociology 57(1): $1-23$. 
Benjamin, Saija and Fred Dervin, eds. 2015. Migration, Diversity, and Education: Beyond Third Culture Kids. Cham: Springer.

Biehl Peter F, Douglas C. Comer, Christopher Prescott and Hilary A. Soderland, eds. 2015. Identity and Heritage. Contemporary Challenges in a Globalized World. New York: Springer.

Castells, Manuel. 2010a. The Information Age. Economy, Society and Culture. Vol. 1. The Rise of the Network Society. $2^{\text {nd }}$ Edition (1st Edition 1996). Oxford: Wiley-Blackwell.

Castells, Manuel. 2010b. The Information Age. Economy, Society and Culture. Vol. 2. The Power of Identity. $2^{\text {nd }}$ Edition and new preface (1st Edition 1997). Oxford: Wiley-Blackwell.

Castles, Stephen, Hein De Haas and Mark Miller. 2013. The Age of Migration. International Population Movements in the Modern World. (5 $5^{\text {th }}$ edition). New York: Palgrave.

Colomer, Laia and Cornelius Holtorf. forthcoming. "What is cross-cultural heritage? Challenges in identifying the heritage of globalized citizens". In: Cultural Heritage, Ethics and Contemporary Migrations, edited by C. Holtorf, A. Pantazatos and G. Scarre. London: Routledge.

Council of Europe. 2005. Framework Convention on the Value of Cultural Heritage for Society ["The Faro Convention"], Strasbourg: European Treaty Series 199. http://www.coe.int/en/web/conventions/full-list/-/conventions/treaty/199 
Council of Europe. 2009. Heritage and Beyond. Council of Europe Publishing. Strasbourg.https://www.coe.int/t/dg4/cultureheritage/heritage/identities/PatrimoineBD_en.pdf

Cresswell, Tim. 2006. On the Move. Mobility in the Modern Western World. London: Routledge.

Cresswell, Tim. 2010. "Towards a politics of mobility". Environment and Planning D: Society and Space, 28: 17-31.

Désilets, Gabrielle. 2015. "Third Culture Kids as serial migrants' children: understanding some of the impacts of a highly mobile transnational upbringing". In: Migration, Diversity, and Education. Beyond Third Culture Kids, edited by S. Benjamin and F. Dervin, 143-162. Cham: Springer.

English Heritage. 2008. Conservation Principles, Policies and Guidance For the Sustainable Managment of Historic Environment. London: English Heritage.

https://content.historicengland.org.uk/images-books/publications/conservation-principles-sustainablemanagement-historic-environment/conservationprinciplespoliciesguidanceapr 08 web.pdf

Fail, Helen, Jeff Thompson and George Walker. 2004. "Belonging, identity, and Third Culture Kids: Life histories of former international school students". Journal of Research in International Education, 3(3): 319-338.

Fassman, Heinz, Max Haller and David Lane, eds. 2009. Migration and Mobility in Europe. Trends, Patterns and Control. Cheltenham: Edward Elgan. 
Fojut, Noel. 2009. "The philosophy, political and pragmatic roots of the convention". In Heritage and beyond, Strasbourg: Council of Europe, edited by Council of Europe, 13-22. Strasbourg.

Friedman, Jonathan. 2007. "Cosmopolitan elites, organic intellectuals and the reconfiguration of the state". In: Figures croisées d'intellectuels, edited by A. Kouvouama, A. Gueye, A. Piriou and C Wagner. Paris: Karthala.

Glick Schiller, Nina. 2010. "A global perspective on transnational migration: theorizing migration without methodological nationalism". In Diaspora and Transnationalism: Concepts, Theories and Methods, edited by R. Bauböck and T. Faist, 109ロ-129. Amsterdam: Amsterdam University Press.

Glick Schiller, Nina and Noel B. Salazar. 2013. "Regimes of mobility across the globe", Journal of Ethnic and Migration Studies, 39(2): 183-200.

Grillo, Ralph. 2003. "Cultural essentialism and cultural anxiety", Anthropological Theory, 3(2): 157-173.

Hannerz, Ulf. 1999. "Reflections on varieties of culturespeak", European Journal of Cultural Studies, 2(3): 393-407.

Harrison, Rodney. 2013. Heritage: Critical Approaches. New York: Routledge. 
Harrison, Rodney and John Schofield. 2010. After Modernity. Archaeological Approaches to the Contemporary Past. Oxford: Oxford University Press.

Held, David and Anthony McGrew. 2003. "The great globalization debate: an introduction". In The Global Transformations Reader: An Introduction to the Globalization Debate. $2^{\text {nd }}$ Edition, edited by D. Held D and A. McGrew, 1-50. London: Polity.

Holtorf, Cornelius and Graham Fairclough. 2013. "The New Heritage and re-shapings of the past". In Reclaiming Archaeology Beyond the Troops of Modernity, edited by A. GonzálezRuibal, 197-210. London: Routledge.

Innocenti, Perla. 2015. Cultural Networks in Migrating Heritage. Intersecting Theories and Practices across Europe. Farnham: Ashgate.

Isar, Yudhishthir, Dacia Viejo-Rose, and Helmut Anheier. 2011. "Introduction". In: Heritage, Memory \& Identity, edited by H. Anheier and Y. Isar, 1-20. London: Sage.

Iyer, Pico. 2000. The Global Soul. Jet lag, shopping malls, and the search for home. New York: Vintage Books.

Kvale, Steinar and Sven Brinkmann. 2009. Interviews: Learning the Craft of Qualitative Research Interviewing. Los Angeles: Sage Publications.

Labadi, Sophia and Colin Long, eds. 2010. Heritage and Globalism. Oxford: Routledge. 
Lindley, Anna and Nicholas Van Hear. 2007. New Europeans on the Move: A preliminary review of the onward migration of refugees within the European Union. Report of the Centre on Migration, Policy and Society. Report No. 57. Oxford: University of Oxford.

Macdonald, Sharon. 2013. Memorylands. Heritage and Identity in Europe Today. Abingdon: Routledge.

Meskell, Lynn. 2009. "Introduction. Cosmopolitan heritage ethics". In Cosmopolitan Archaeologies, edited by L. Meskell, 1-27. Durham/London: Duke University Press.

Meskell, Lynn, ed. 2015. Global Heritage. A Reader. Chichester: Wiley Blackwell.

Moore, Andrea and Gina Barker. 2012. "Confused or multicultural. Third culture individual's cultural identity", International Joumal of Intercultural Relations, 36: 553-562.

Ossman, Susanna. 2013. Moving Matters. Paths of Serial Migration. Stanford: Stanford University Press.

Papastergiadis, Nikos. 2000. The Turbulence of Migration: Globalization, Deterritorialization and Hybridity. New York: John Wiley \& Sons.

Pollock, David and Ruth Van Reken. 2009. Third Culture Kids. Growing Up Among Worlds (revised edition). Boston/London: Nicholas Brealey.

Remarque Koutonin, Mawuna. 2015. "Why are white people expats when the rest of us are 
immigrants?", The Guardian, 13 March 2015. http://www.theguardian.com/globaldevelopment-professionals-network/2015/mar/13/white-people-expats-immigrants-migration

Ross, Cathy. 2015. "From migration to diversity and beyond: The Museum of London approach". In Museums, Migration and Identity in Europe. People, Places and Identities, edited by C. Whitehead, K. Lloyd, R. Eckersley and R. Mason R., 61-80 Surrey/Burlington: Ashgate.

Salazar, Noel B. 2012. "The power of imagination in transnational mobilities", Identities: Global Studies in Culture and Power, 18(6): 576-598.

Sayand, Abdelmalek. 1999. La double absence. Des illusions de l'émigré aux suffrances de l'émigré. Paris: Le Seuil.

Scholte Jan Aart. 2005. Globalization. A Critical Introduction (2nd Edition). Basingstoke: Palgrave.

Schofield, John. 2015. "Forget about 'Heritage': place, ethics and the Faro Convention". In The Ethics of Cultural Heritage, edited by T. Ireland T and J. Schofield J., 197-209. New York: Springer.

Skrbi $\square$, Zlatko and Ian Woodward. 2013. Cosmopolitanism. Uses of the Idea. London: Sage.

Solms, Mark and Olivier Turnbull. 2002. The Brain and the Inner World. London: Karnac. 
1

Svašek, Maruška. ed. 2012. Moving Subjects, Moving Objects. Transnationalism, Cultural Production and Emotions. Oxford: Berghahn.

Tanu, Danau. 2015. "Toward an interdisciplinary analysis of the diversity of "Third Culture Kids". In Migration, Diversity, and Education. Beyond Third Culture Kids, edited by S. Benjamin and F. Dervin, 13-35. Cham: Springer.

Tomlinson, John. 2003. "Globalization and cultural identity". In The Global Transformations Reader: An Introduction to the Globalization Debate. $2^{\text {nd }}$ Edition, edited D. Held and A. McGrew, 269-277. London: Polity.

Trąbka, Agnieszka. 2014. "Being chameleon. The influence of multiple migration in childhood on identity construction". Studia Migracyne. Przeglad Polonijny, 3 (153): 87-105.

United Nations. 2013. International Migration Report 2013. Department of Economic and Social Affairs, Population Division. New York: United Nations. http:/www.un.org/en/development/desa/population/migration/publications/migrationreport/d ocs/MigrationReport2013.pdf

Urry, John. 2000. "Mobile sociology", British Journal of Sociology, 51(1):185-203.

Urry J 2007. Mobilities. London: Polity.

Vertovec Steven. 2007. "Superdiversity and its implications", Ethnic and Racial Studies, 30(6): 1024-1054. 
Wasserman, Lesley and Debby Zambo. 2013. Early Childhood and Neuroscience - Links to Development and Learning. New York: Springer.

Wikan, Unni. 1999. "Culture: a new concept of race", Social Anthropology, 7(1): 57-64.

Winter, Tim. 2014. "Heritage studies and the privileging of theory". International Journal of Heritage Studies, 20 (5): 556-572. 